研 究

キャラメルおよび飴菓子の水分定量

一ホルムアミドを溶娮とするカール

フィッシャー法とフィルム法の比較一

室井 要* ・堤 忠一** - 小泉英夫**

Determination of Moisture in Caramel and

Sugar Candy: Comparison of the Karl-

Fischer titration method using formamide as solvent with the film method

Kaname Muroi, Chuichi Tsutsumi, and Hideo Kolzumi

The Karl-Fischer titration method (KF method) employing a mixture of formamide-methanol (2:1) for dissolving sample and the film method employing small bag of high density polyethylene film for drying were applied for moisture determination on caramel and sugar candy. With 25 $\mathrm{m} l$ of the solvent, $0.2-0.4 \mathrm{~g}$ caramel was dissolved at $55-60^{\circ} \mathrm{C}$, and then titrated by the $\mathrm{KF}$ reagent. In case of sugar candy, dissolving was conducted on 1-2 $\mathrm{g}$ sample at room temperature. This $\mathrm{KF}$ method was rapid, and the relative errors obtained on several samples of caramel and sugar candy were $\pm 0.1 \%$ and $\pm 0.02 \%$, respectively. Moisture in these samples was determined with satisfactory accuracy and precision by the film method of drying at $100^{\circ} \mathrm{C}$ under $20-30 \mathrm{mmHg}$ for 2 or 4 hours. The relative error was $\pm 0.05 \%$. The difference in the moisture values obtained with these two methods on the same samples was within $0.1 \%$.

(Recived June 11, 1968)

キャラメルおよび飴菓子の水分の一般的な 定量方法 は，石英砂，ケイソウ土などの乾燥助剂を用いる加熱乾

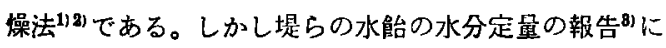
よると，乾燥助唷を用いる方法は誤差を伴いやすく，ブ ラスチックス・フィルム袋を用いる減庄乾橾方法（以下 フィルム法と略記する）がより簡易で正確であるという 結果が得られている。このことからキャラメル類およ び能菓子の水分定量にフィルム法の適用を試みた。
いっぽうカールフィッシャー法（以下K F 法と略記す る）は真の水分を定量する方法として従来から多くの食 品に適用されて来た。しかし，その場合，試料が可溶性 であるか，試料中の水が滴定用溶冎で抽出される必要が ある。キャラメルや飴菓子は溶郩にとけにくいため，必 ずしも K F 法が勃果的とはいえなかった。

しかし，食品の水分定量の抽出溶削 ${ }^{4151}$ ，および糖類の 溶郕にホルムフミドを適怘している報告ももある。これ らのことからわれわれはキャラメル類および飴類の水分 をK F 法で定量するさいの試料溶剒として，ホルムてミ ドとメタノールの 2:1 の混合溶戍を用いる定量条件を 検討し，簡易，迅速に定量できることがかかったのでフ イルム法による定量值と比較した。

1. 実験方法

（1）試料および採取方法

試料は市販品の各種キャラメルと飴菒子を用いた。キ ナラメルは粒のまま適宣に切って用い, 飴菓子は乳釾で 20〜30メッシニに粉研, 均一化して用いた。

（2）KF法による定是

i) 装置および試薬：筒井理器 (株) 製, KFD-15 形 加温抽出用電気滴定装置を用い，三菱化成製 K F 試薬 $\mathbf{S}$ $\mathrm{S} \Gamma$ 「ッビシ」, 力洒 $3 \mathrm{mgH} 2 \mathrm{O} / \mathrm{ml}$ で滴定した。溶削は 試薬 1 級ホルム厂ミドを水銀柱 $10 \mathrm{~mm}$ の減圧下, $102^{\circ} \mathrm{C}$ で留分を集め (水分 $0.02 \%$ ), 脱水木ルムフミドとし, これに無水メタノールを混合して用いた。

ii) 定量操作：滴定フラスコに溶㓱 $25 \mathrm{~m} l$ をとり，あ らかじめK F 試薬で無水にし, 試料を試料採取投入ビン に採り，一定量を投入し，常温または $55 \sim 60^{\circ} \mathrm{C} て ゙$ 溶解 し，KF試薬で直接滴定した。キャラメルは $5 \times 5 \times 2$ $\mathrm{mm}$ 角に载断して採取した。

(3) フィルム法による定量

所定の温度が $\pm 0.5^{\circ} \mathrm{C}$ に調節てきる減圧用電気定温 乾燥器を用いた。科量および乾燥容器となるポリエチレ

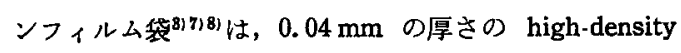
ポリエチレンフィルム製, $7 \times 12 \mathrm{~cm}$ の袋を用いた。

フィルム袋は $100^{\circ} \mathrm{C}$ で1時間予乾しキャラメルは $1 / 3$ 粒，その他は 1.5 2.0 g をフィルム绞に採取し精 秤し, $100^{\circ} \mathrm{C}$ の乾燥器で軟化させ, 袋の外から圧延して

*三菱化成工業株式会社商品研究所（神奈川県川㥓市久本軞居町）

Market Development Research Lab., Mitsubishi Chemical Industries, Ltd. Kawasaki, Kanagawa.

** 農林省食提研究所（東京都江東区塩捠 1-4-12)

Food Research Institute, Ministry of Agriculture and Forestry. Koto-ku, Tokyo. 
第 1 表 KF 法による定量条件の検討

\begin{tabular}{|c|c|c|c|c|c|c|c|c|}
\hline 尌料名 & & $\neq+\quad \xi$ & + & & & 始 & 蒋 & \\
\hline & $\Rightarrow y-4$ & チaコレート & フーモトン & ミルク & 玉 & ハேーー佁 & トロッフ & 水 \\
\hline 探 取 & $0.14 \sim 0.29$ & $0.14 \sim 0.21$ & $0.19 \sim 0.24$ & $0.16 \sim 0.25$ & $0.50 \sim 0.69$ & $0.62 \sim 0.83$ & $0.88 \sim 1.05$ & $0.08 \sim 0.09$ \\
\hline 水分平均値 ${ }^{*}(\%)$ & 7.81 & 9.09 & 7.02 & 7.87 & 4.66 & 2.81 & 2.00 & 14.52 \\
\hline 所 要 時 間 (分) & 20 & $20 \sim 30$ & 25 & $20 \sim 30$ & $15^{* *}, 30$ & $6 \sim 8$ & 10 & 15 \\
\hline バラッキの幅 (\%) & 0.12 & 0.18 & 0.01 & 0.56 & 0.03 & 0.01 & 0.02 & 0.27 \\
\hline
\end{tabular}

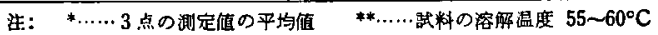

試料を薄くのばし，袋の口を開いて，减圧乾燥器中に入 れ，水銀柱 $20 \mathrm{~mm}$ の減圧下で 1 洔間または 2 洔間乾燥 し，そのつどとりだしてデシケーター中で 20 分間放冷 後科量し,この操作を繰り返えした。

\section{KF 法による定量条件の検討}

（1）溶剂混合比と試料の溶解速度 ホルムアミドは糖類の溶削として単独にも用いられる が，一般にK F 法で使われるメタノールと混合して適用 できれば滴定が円滑に進行するので好都合と考え，キャ ラメルを試料とし，各種混合比の溶削を調製し，この溶 绪 $25 \mathrm{~m} l$ に試料約 $0.4 \mathrm{~g}$ を投入し溶解試験を行なった結 果, ホルムアミドとメタノールの混合比を $2: 1$ にする ともっとも効果的であることがわかった。

(2) 試料採取量と試料の溶解速度

キャラメル類は溶解速度がおそいので， $0.15 \sim 0.4 \mathrm{~g}$ を採取し，55 $60^{\circ} \mathrm{C}$ に加温して溶解した。この範囲内 での定量所要時間は 20〜30 分であった（第 1 表)。

飴菓子類は粉砕試料であることも一因で，溶解性がす ぐれ，0.5〜 $1.0 \mathrm{~g}$ を採取したさい，飴玉以外は常温下 10〜15 分で定量できた。

$25 \mathrm{ml}$ の溶绪は, 試料を 3〜4 回連統して溶解し, 定 量を繰り返えすことができた。

(3) 定量值の検討

第1表のとおりであり，キャラメル類は試料の種類に よって，3点の值は $0.01 \sim 0.56 \%$ とバラッキがあり, このことは，あとにのべる粒の個体間の水分のバラッキ を検討した紹果から，粒相互の水分の違いが大きく影部 していると考察される。

飴菓子は，水飴を除くと $0.03 \%$ 以内のバラッキで， よく一致している。

\section{3. フィルム法による定量条件の検討}

(1) 乾燥温度

キャラメルは乾燥温度を $70^{\circ}$ と $100^{\circ} \mathrm{C}$ として乾燥し たときの定量值は第 2 表に示す。 $70^{\circ} \mathrm{C}$ では, 25 時間乾 燥したとき, 3 点の定量值が一致するようになり，100 $\mathrm{C}$
で 2 時間乾燥した場合の定量值と一致した。

$100^{\circ} \mathrm{C}$ の乾懆では，1時間でも 3 点の定量值は一致 し， 2 時間との差は， $0.1 \%$ 以内であり，一応 2 時間乾 燥する条件を選んだ。

(2) 試料個体間の水分のバラッキ

定量法の比較検討の試料とするため, 試料粒子間のハ ラッキを，第3表に示した各種試料につき，各容器から 3 粒ずつを採取してフィルム法で定量した。Gキャラメ ルは 2 回採取した 3 䊀とも非常にバラッいた値で $1 \%$ の

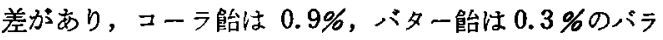
ッキであった。このことから，あとにのべる比較検討の キャラメル試料は, 容器内の䊀子間の水分のパラッキの ないものを選んで用いた。

(3) 試料探取量の影響

採取量は，第2，3 表に示したように 1２ g の範囲 で,とくに值のバラッキがなく, 精度, 正確さとも満足 できるむのと考えられた。

\section{KF 法とフィルム法の比較}

同一試料を用い，两方法での結果を，第 4 表示にす。

(1) キャラメル類

フィルム法による定量值は,フーモンドを除外し，す

第 2 表 フィルム法による定量

\begin{tabular}{|c|c|c|c|}
\hline \multicolumn{2}{|c|}{ 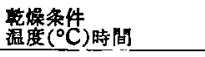 } & 水分平均值 $(\%)^{*} 1$ & ハラッキの愊 \\
\hline \multirow{4}{*}{70} & 3 & $7.18 * 2$ & 0.21 \\
\hline & $5(8)^{* 8}$ & 7.55 & 0.15 \\
\hline & $5(13)$ & 7.65 & 0.06 \\
\hline & 12 (95) & 776 & 0.02 \\
\hline \multirow[t]{2}{*}{100} & $2.5^{* 1}$ & 7.86 & 0.03 \\
\hline & 1 & $7.68 * 2$ & 0.02 \\
\hline \multirow[t]{2}{*}{100} & $1(2)$ & 7.73 & 0.01 \\
\hline & $3(5)$ & 7.8 & 0.02 \\
\hline
\end{tabular}

注： 1,3 点の测定䛧の平均値

2, 試料㟫取量 $1.44 \sim 1.57 \mathrm{~g}$

*3, ( ) 内数字は合的時间

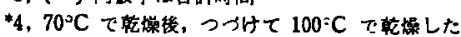


第 3 表 試料個体間の水分のバラッキ(フィルム法による定量)

\begin{tabular}{|c|c|c|c|c|c|c|c|c|c|}
\hline \multirow{2}{*}{ 政 } & \multirow{2}{*}{ 名 } & \multicolumn{2}{|r|}{$\neq$} & \multirow[t]{2}{*}{+} & $\overline{3}$ & \multicolumn{2}{|l|}{ ル } & \multirow{2}{*}{$=$ 皓 } & \multirow{2}{*}{$\frac{子}{\therefore}$} \\
\hline & & ミルク (1) & ミルク (2) & & $\mathbf{A}$ & G (1) & G (1) & & \\
\hline 採 取 基 & $(\mathbf{g})$ & $1.38 \sim 1.64$ & $1.47 \sim 1.49$ & & $.29 \sim 1.34$ & $1.34 \sim 1.45$ & $1.42 \sim 1.47$ & $1.35 \sim 1.50$ & $1.31 \sim 1.60$ \\
\hline 水分平䏴値 & $(\%)^{*}$ & 7.65 & 8.63 & & 6.58 & 8.19 & 8.00 & 3.55 & 2.64 \\
\hline ハラッキの梮 & $(\%)$ & 0.10 & 0.08 & & 0.08 & 0.91 & 0.65 & 0.93 & 0.27 \\
\hline
\end{tabular}

生：*..3 点の测定值の平均值

第 4 表 $\mathrm{KF}$ 法とフィルム法による水分定量值の検討

\begin{tabular}{|c|c|c|c|c|c|c|c|c|c|c|c|}
\hline & \multirow{2}{*}{ 訊 料 } & \multirow{2}{*}{ 各 } & \multicolumn{2}{|r|}{ 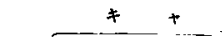 } & \multirow{2}{*}{$\frac{F}{\eta !-4}$} & \multirow{2}{*}{$\frac{ル}{\text { アーモント }}$} & \multirow[b]{2}{*}{ 㕷 玉 } & \multirow{2}{*}{ 咕 } & 菓 & \multirow{2}{*}{ 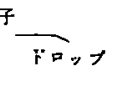 } & \multirow{2}{*}{ 水 蛣 } \\
\hline & & & $\Sigma ル \cdot ク$ & $f: 3 レ-1$ & & & & & 黑 站 & & \\
\hline (사) & フィルム法*1 & $(\%)$ & 8.03 & 7.97 & 7.02 & 6.58 & 4.41 & 2.38 & 2.62 & 2.44 & 14.55 \\
\hline \multirow[t]{2}{*}{ (b) } & $\prime \prime \quad *_{2}$ & $(\%)$ & & & & & 4.47 & 2.44 & 2.74 & 2.96 & \\
\hline & バラッキの柏 & $(\%)$ & 0.08 & 0.06 & 0.07 & 0.08 & 0.03 & 0.02 & 0.07 & 0.12 & 0.03 \\
\hline \multirow[t]{4}{*}{ (C) } & K F 法 & $(\%)$ & 8.12 & 8.02 & 7.11 & 6.52 & 4.58 & 2.65 & 2.72 & 2.53 & 14.51 \\
\hline & ハシッキの恦 & $(\%)$ & 0.09 & 0.19 & 0.13 & 0.33 & 0.03 & 0.02 & 0.03 & 0.02 & 0.09 \\
\hline & (견-() & & -0.09 & -0.05 & -0.09 & +0.06 & -0.17 & -0.27 & -0.10 & -0.09 & +0.04 \\
\hline & (b-C) & & & & & & -0.11 & -0.21 & +0.02 & +0.43 & \\
\hline
\end{tabular}

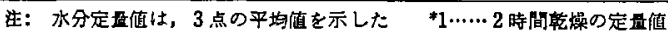

ベてK F 法より約 $0.1 \%$ 低い。值のバラッキは,フィ ルム法で 0.1\%，KF法で 0.1〜0.3\% を示し，後者の 試料採取量が少ないため, 定量誤差がやや大であると考 えられる。フィルム法とK F法による定量值が $0.1 \%$ の 差で一致したことから，フィルム法で正確に定量でき， 精度もすぐれていると判断される。KF法も，バラッキ を考虑して用いるなら，迅速性において有利さがある。

\section{(2) 飴菓子類}

フィルム法の定量值は，水飴を除くといずれも K F 法 より，0.1〜0.3\% 低く，乾燥不十分と考えられ，なお 2 时間乾燥すると，ハターボールで $0.2 \%$ 低く，それにひ きかえ,フルーッドロップは逆に 0.4\% 高くなった。

值のバラッキは両方法，どの試料も $0.1 \%$ 以内で満足 されるが,フィルム法では, 乾燥時間により定量値が一 定でない試料るあるので, これら飴菓子類の水分は, KF 法のほうが精度,正確さともすぐれていると判断される。 水飴の定量值は，両方法とも一致したが，K F 法は試 料採取量を多くできないので，ハラックことがある。

5. 要 約

(1) 試料の溶解にホルムアミドとメタノールの 2:1 の混合溶刘を用いるK F 法は，従来の方法より，迅速性， 再現性，正確さにおいてすぐれている。キャラメルは $55 \sim 60^{\circ} \mathrm{C}$ で溶解し，K F 試楽で直接滴定し, 所要 時間 -25〜30 分で, 相対誤差 $\pm 0.1 \%$ で定量できる。啷菓子
は常温で溶解し，直接滴定することにより，所要時間 10〜20 分で，相対誤差 $\pm 0.02 \%$ で定量できる。

（2）フィルム法は，水銀柱 $20 \mathrm{~mm}$ の減圧下， $100^{\circ} \mathrm{C}$ でキャラメルは 2 時間, 飴菓子は 4 時間乾燥すること により，相对誤差 $\pm 0.05 \%$ の正確さで定量できる。

（3）ＫＦ法とフィルム法を比較した結果，両方法に よるキ+ラメルの定量は，0.1\%以内でよく一致した。 しかし、フィルム法の跆菓子の定量值は, 試料によって KF法よりも高く，飴菓子の水分は，K F 法が正確であ ると考えられる。

文献

1) A.O.A.C.: Methods of Analysis of A.O.A.C., 10th. ed., p. 486, 513 (1965).

2）设粉糖技術研究会：使粉糖工業分析法， p. 4 (1959).

3）堤 忠一・永原太郎：食品工誌，10，447 (1963).

4) MсСомв, E. A. and Wright, H.M.: Food Technol., 8, (2), 73 (1954).

5) Rader, B.R.: J. Assoc. Offic. Anal. Chemists, 49, (4), 726 (1966).

6) МсСомв, E.A.: Anal. Chem., 29, 1375 (1957).

7）堤 忠一一小泉英夫・佐藤友太郎：食品工誌, 11, 290 (1964).

8）堤 忠一・小泉英关・宫崎芳子 - 海老根英雄：食 品工誌, 13, 339 (1966).

(1968 年 6 月 11 日受理) 